\title{
ФІЛОСОФСЬКА ОНТОЛОГІЯ
}

\author{
UDC 1.125 \\ DOI https://doi.org/10.24195/spj1561-1264.2020.2.1
}

\author{
Guyvan Petro Dmytrovych \\ Candidate of Juridical Sciences, Honored Lawyer of Ukraine, \\ Professor \\ Poltava Institute of Business \\ 7 Sinna str., Poltava, Ukraine
}

\section{THE STUDY OF THE ESSENTIAL NATURE OF TIME IN THE CONTEXT OF PERCEPTION OF THE FUNDAMENTAL PHENOMENA OF EXISTENCE}

\begin{abstract}
This work is devoted to the study of a very important in science question about the content and essence of time, its relationship with spatial phenomena and perceptions of these processes by man. After all, it is in the human consciousness that the passage of time can only manifest outward changes in specific phenomena in relation to past events and their expectations in the future. The essence of time is analyzed, which in human perception is a phenomenon characterized by a special emotionality of awareness as a factor that determines the temporality of our stay on earth. In this context, there are serious difficulties in the process of cognition of time. The controversy in philosophical science is analyzed as to whether time is an objective manifestation of the real material world, or, conversely, it is in the plane of subjective perception, that is, acts as a certain spiritual phenomenon. Philosophical ideas that denied the objectivity of time or its existence in general, which were quite popular during the long development of scientific thought, were studied. Particular attention in the work is paid to the perception of temporal manifestations of matter within the ontology, the section of philosophy that studies the fundamental principles, the general categories of being. The theory of ontological idealism is considered, the main idea of which was that the ideal perception forms in the mind significant differences between the object and its imaginary image. According to this concept, time is perceived as a psychological fact, the inner experience of the human soul. Specific phenomena of nature are interpreted mainly from a subjectivist standpoint, and the important philosophical category of "things in themselves" as something objectively existing is not recognized outside the consciousness of the subject. The so-called "transcendental" direction is evaluated separately. According to the paradigms of this concept, space and time are a priori forms of contemplation, which seek to provide certainty and order to cognition, but in themselves are not part of it. This is the transcendence of space and time, and counteracting the empirical knowledge.
\end{abstract}

Key words: time course, present, past, future.

Introduction. Matter is in constant motion, and this motion occurs in a certain space and time. Space and time are forms of existence (being) of matter. Space determines the length (geometric dimensions) of material objects and characterizes their interaction, while time determines the duration of existence of these objects and the sequence of their change. In other words, the content of matter is concrete objects, and the form of their existence, as well as all matter, is time and space, which are characterized by such characteristics as objectivity, irreversibility (for time) and recognizability. For many millennia, mankind has tried to comprehend the time course, to create a holistic system of knowledge about time, its properties, structure, to create theories of knowledge. In our daily life we constantly feel the time factor in any sphere of our practical activity. This applies to both economic and social relations and the sphere of knowledge of various aspects of life around us. Material objects, socio-political relations, norms of law, ethical and aesthetic principles cannot be unchanged, they are necessarily subject to temporal influence. The question of time and duration of certain legally significant acts occupies an extremely important place in legal science. It is one 
of the main themes of scientific reflection, because it is with the temporal dimensions of different in nature and content of legal phenomena significantly depends on the very nature of social relations. The question "what is time, what is the meaning of this phenomenon" has long been of interest to scientists, from philosophical to apologists for classical and relativistic physics: they all tried to understand the meaning of time, to understand its nature and essential properties.

Purpose and objectives. This topic is very relevant, this is primarily due to the fact that time belongs to the list of fundamental general categories that have a defining, formative methodological value for a real understanding of the existing relationships in the universe and the relationship of reality and cognition. After all, with each passing period, the density of past events increases, the flow of information increases, which is perceived and re-evaluated each time, both by society and by each individual. This encourages the periodic questioning of the importance of time, its role and manifestations in the surrounding reality. Time is the all-encompassing factor that makes it possible to make an essential connection between events and phenomena that occur in space, giving them a proper perception of their place in the system of interactions of various phenomena of a particular being. As Thales of Miletus once claimed, the wisest time is because it reveals everything [1].

Research methods. The research of these scientists was aimed at providing a general description of the concept of temporal motion, its forms, properties and structure, including the ratio of time categories of present and past and future, within the ontology as the main scientific method in this field. But the doctrine currently lacks an analysis of the effectiveness and efficiency of studying the process of how time correlates with other natural phenomena and has its own personal characteristics in terms of the interaction of different temporal aspects. This is largely important for characterizing the relationships of different time states. The study of individual approaches to the effectiveness of such interaction, which ultimately determines the essence, the quintessence of time and can be defined as the unity of the past, present and future, is the purpose of this scientific article.

Results. Time in human perception is a phenomenon that is characterized by a special emotional awareness as a factor that determines the temporality of our stay on earth, it is an indicator that regulates life expectancy, and hence - periods of legal acts committed by a person to regulate any material legal relations. On the other hand, the temporal laws of existence are the least studied. Even in the field of philosophical science, which is the basis of the vision of the essence of the main processes in the world, the concept of time and its content and basic manifestations are not established and defined. Moreover, it is postulated that modern man, like his ancient ancestors, continues to have no influence on the passage of time. It, as well as its individual properties, is a mystery to mankind not only in the fields of micro- and megaworlds, which are available for applied research, but also at the level of our domestic experience [2, p. 3-4]. We must state that there are serious difficulties in the process of cognition of time. At first glance, it would seem that time is an everyday, largely everyday category that is familiar and commonplace in our lives. However, his more meticulous study with the identification of characteristic features and properties inevitably encounters obvious difficulties: time is not subject to detailed consideration, like other properties of objects. There are signs of problems, both objective and subjective. The first is the place of observation of the phenomenon under study. Man and any of his actions, including the laws of building social relations, various legal and customary acts, cannot remain beyond time. They are not outside certain actions that take place in space, and with them, regardless of whether a particular subject is a participant or not, travels in time.

Exploring the essence of time and its main properties, usually the first question that arises is: is time an objective manifestation of the real material world, or, conversely, it is in the plane of subjective perception, that is, acts as a certain spiritual phenomenon. After all, doubts about the objectivity of the existence of time are well-founded. For example, in nature there can be no such phenomenon, the constituent elements of which have already ceased to exist, or it has not yet begun. Such an analysis led Aristotle to the idea of the ephemerality of time: time does not exist, because one part of it already was, and it is not now, the other will be, but it is not yet. These parts consist of both infinite time and its allocated interval. But what does not exist cannot be proper to existence [3]. Philosophical ideas that denied the objectivity of time or its existence in general 
were quite popular during the long development of scientific thought. Example. I. Kant postulated that time and space are forms of our sensitivity, our mind, the innate ability of man to put in order various things and events. Taking into account scientific developments, special terms appeared that characterized the essence of the temporal properties of the object of observation: biological time, social time, psychological time, etc. In fact, the development of our ideas about the space-time motion of matter are successive stages in the development of human cognition. Today in the literature we can find three definitions of these categories: real, perceptual and conceptual space and time. Real space-time is postulated as objectively real forms of existence of matter, conditions of coexistence of objects. Perceptual space and time express the conditions of existence and change of our ideas and other mental acts of the subject. Finally, conceptual space and time are abstract mathematical structures that can model real space-time relations [4, p. 24]. The latter approach is used in the study of the properties of time within physical science. The special science of relationships in time is called chronometry, the interaction of conceptual time with space is studied within chronogeometry. However, by and large, the conceptual questions of the essence of time are problems of philosophy.

Historically, the question of being, its forms, properties and structure, including space, time, motion, was studied within the ontology - the doctrine of being [5, p. 145], a section of philosophy that studies the fundamental principles, the general categories of being. Ontology tries to make a general outline of the phenomena existing in nature, thus not being reduced to developments of separate sciences. One of the main categories that characterize a certain phenomenon in the ontology as real, objective and independent of human consciousness is the concept of matter. Matter as a philosophical category is perceived not because of its individual specific properties, but because of the general, comprehensive and abstract nature of its manifestations. It does not contain any definite features, but is only the result of abstract human thinking. Thales, Anaximander, Aristotle, and Plato were considered to be the first scholars who made a significant contribution to the development of issues of ontological orientation within European philosophy. Identifying time with eternity, they qualified it as an independent manifestation, a pure duration that flows evenly, in the end, as a container of events [6]. Their awareness of matter was based on the principles of materialist perception. In particular, Aristotle, assessing the manifestations of the motion of matter as a separate substance noted that they are not perceived at the level of direct sensations, the recognition of its existence is due to the generalization of our observations.

With the further development of science, the ontological theory of idealism became widespread, emphasizing the subjective and figurative reflection of being in the human mind. The basic idea here was that ideal perception forms in the mind essential differences between an object and its imaginary image. An image does not have all the physical properties of a particular object, because it is devoid of corporeality, it is not material. Therefore, space and time were imagined as ways of arranging matter through cognition, so they have a psychological origin. Time was perceived as a psychological fact, the inner experience of the human soul. Significant research within the idealist theory was carried out by such philosophers as Augustine, Thomas Aquinas, F.V. Schelling, and G.V. Hegel. Thus, philosophical thought began to tend to denote the concept of matter through the cognition and consciousness of man as the recognition of real objective phenomena that exist independently of it, but are reflected as such in consciousness through sensations. Space and time were interpreted as manifestations of human sensitivity, cognition. It was believed that human subjectivity is not reduced to objective-material manifestations, is a specific way of being of consciousness, inherent only in the thinking person. It cannot be manifested objectively and studied by scientific methods, but due to its mental comprehension a person constitutes the surrounding nature into a certain image endowed with spatio-temporal criteria. According to this theory, specific phenomena of nature are interpreted mainly from subjectivist positions, and an important philosophical category of "things in themselves" as something objectively existing is not recognized outside the consciousness of the subject [7, p. 76]. A similar approach was also characterized by the study of the French philosopher A. Bergson, who analyzed time in the context of its experience by man as a living conscious being. The essence of such a subjective and irreversible time was determined by the scientist exclusively through the category 
of duration. Since duration is the course of a person's inner life, the only carrier of time will be the subject. Therefore, our feelings about real material phenomena, reflected in the internal duration, and create the time of the external world [8, p. 40-41].

Ontological cognition received a separate development within the so-called "transcendental" direction. The advancement to the truth here acquired the defining origins of pure sensuality, which is reflected in transcendental aesthetics. According to the paradigms of this concept, space and time are a priori forms of contemplation, which seek to provide certainty and a certain order to cognition, but in themselves are not part of cognition. This is the transcendence of space and time, and this is the counteraction to the empiricism of cognition. Over time, the general principles of existence began to be considered at the level of supersensible, suprarational intuition: it was argued that they are manifested only intuitively, not during practical, cognitive human activity, the interaction of subject and object. The most prominent supporters of the "transcendental ontology" were such representatives of the German philosophical school as I. Kant, M. Heidegger, E. Husserl and others. Thus, Kant denied the objective existence of time, as well as space, and therefore considered it impossible to empirically perceive it either directly or indirectly. He pointed out that time as an a priori part of the cognitive apparatus has some objective significance only in relation to phenomena, things that we, in turn, perceive as objects of our feelings. Therefore, time really does not exist as an object, but as a way of representation, and in this sense it is a subjective reality [9, p. 139-140; 248-249]. In Kant's philosophy, a priori forms of cognition are defined as transcendental. They are a prerequisite for all experience and constitute our perception. Transcendental forms of sensuality are space and time, transcendental forms of consciousness are categories (substance, causality, etc.). In turn, transcendental forms of consciousness are regulatory ideas of pure reason (ideas of God, soul, world as a whole). The transcendental (a priori) opposes, on the one hand, the empirical (based on experience, a posteriori), which it forms, and on the other hand - the transcendent - because it goes beyond experience, things in themselves.

E. Husserl recognized as a tool of knowledge not science itself, but its positivist interpretation, or fetishized science: he pointed out that the difference between immanent and transcendent perception reflects the difference between how experience and being, and consciousness [10, p. 133]. In other words, the main ontological principle here is subjectivity: the subject is the transcendental consciousness, from which everything objective is reduced [11, p. 86]. Thus, the concept of increasing the value of "I" in each act of cognition as an absolute starting point comes to the fore. This, in particular, was the antimetaphysical orientation in elucidating the essence of man as a creative being. On the other hand, an object is understood as an intentional phenomenon that emphasizes its connection with the subject. Thus, objectivity is characterized as a product of spirituality, a product of vital subjectivity, and the object is the subject of consciousness [12, p. 410-411].

As we see, according to this concept, the relationship between object and subject is reduced to the definition of the former last, and the degree of this constitution depends on the level of comprehension in the form of universality, which ultimately separates the categories "now" and "here" experience, contained in the term "objectivity of thinking". Therefore, the highest degree of logical activity of the intellect is intuition [13, p. 384]. However, intuitive theory has the disadvantage that it focuses mainly on contemplation of the existing and does not take into account the element of historicity in the existence of matter. Modern researchers, as a rule, do not support the idea of cognition of being as a universal manifestation of pure consciousness and the interpretation of intentionality as an allencompassing phenomenon that occurs in the relationship of actual and potential impressions. Not only the knowledge of existing, or presented as existing, objects encompasses the process of studying being. We must take into account other experiences, first of all, non-intentional, i.e. not aimed at existing objects [14, p. 131]. Finding the truth in the process of intuition is not determined by socio-historical factors. In fact, the truth could have been revealed both today and a thousand years ago. As E.M. Prichepiy figuratively points out, the absolute truth turns into a minted coin, which is randomly selected. Thus, the necessity and absoluteness of phenomenological truths returns by chance of their comprehension [11, p. 52]. We are talking about the knowledge of being in the context 
of its movement, which means that we must take into account all the factors of progress of matter, including temporal. Being moves in space and time, something has happened and ceased to exist, something continues, exists simultaneously, together or separately with something else, something will just happen. But even if a certain phenomenon is over, it still contains some remnant of being, which is manifested in its superimposition on the present and the future, and when the event has not yet occurred, it is also part of the universe, although the weight of its impact on the past and present weaker, deficient. Therefore, the experience of cognition should cover all things, including those that have already disappeared or have not yet emerged.

It should be understood that the past and the future as temporal manifestations of the movement are important only for the formation of the realities of the present. All three modes of time - past, present and future - are manifested outwardly and are known only through their manifestation now in a specific moment of the present time. They have their own characteristics of reproduction in the mind, as elements of memory, observation and active participation, and creative expectation, respectively. In the process of his activity, a person is able to set specific micro- and macrotime intervals quite accurately. This is done by using a reflex based on established skill processes that are complicated by acquired temporal extrapolation. This subconscious ability, modeled and compared with the ability of man to consciously estimate time, is the ability to apply temporal manifestations measured by man, and extrapolate them to real relationships occurring in space.

Some conclusions can be drawn from the study. Although time as a phenomenon is the most common object of evaluation by scientists, it is also the phenomenon that is most difficult to understand, and the results of research are as ambiguous as possible. Indeed, we must state that there are serious difficulties in the process of cognition of time. At first glance, it would seem that time is an everyday, largely everyday category that is familiar and commonplace in our lives. However, his more meticulous study with the identification of characteristic features and properties inevitably encounters obvious difficulties: time is not subject to detailed consideration, like other properties of objects. Indeed, when calculating and establishing the temporal characteristics of the object in various areas of research, including those relating to the temporal regulation of legal relations, there are certain problems, because our ideas about absolute time are not consistent with reality: time has a much closer relationship with a variety of factors that determine the existence of bodies in space than is usually postulated. However, to solve the problems posed by law, and in particular civil, such a temporal view is sufficient: it is the absolute time and the objective laws of its course mediate the development of material legal relations in society.

\section{BIBLIOGRAPHY}

1. Філософія і релігієзнавство. URL: https://tureligious.com.ua/fales-miletskyj/.

2. Подольный Р.Г. Освоение времени. Киев : Наукова думка, 1984. 144 с.

3. Аристотель «Физика». Гл. IV. URL: http://lib.ru/POEEAST/ARISTOTEL/ physic.txt.

4. Солдатов А.В. Понятия пространства и времени в структуре естественнонаучной теории. Ленинград : Изд-во ЛГУ, 1981. 72 с.

5. Ажимов Ф.Е. Онтолого-метафизические проекты современной западноевропейской философии. Вопросы философии. 2007. № 9. С. 145-153.

6. Plato. Timaeus. Opera. Vol. 4. Ed. J. Burnet. Oxf., 1900. 38 p.

7. Kant Immanuel. Prolegomena zu einer jeden kunftigen Metaphysik, die als Wissenshaft wird auftreten konnen. Philipp Reclam jun. Stuttgart, Meiner, F 2001. 200 s.

8. Бергсон А. Длительность и одновременность. / Пер. с фр. Петербург : ACADEMIA, 1923. $154 \mathrm{c}$.

9. Кант И. Сочинения в шести томах. Т. 3. Москва : Мысль, 1964. 799 с.

10. Husserl E. Ideas: General Introduction to Pure Phenomenology / translated by W.R. Boyce Gibson. London : George Allen \& Unwin Ltd., 1931. 465 p.

11. Причепій Є.М. Феноменологічна теорія свідомості Е. Гуссерля. Київ : Наукова думка, 1971. 104 c.

12. Gurwitsch A. Der Begriff des Bewusstseins bei Kant und Husserl. Kantstudien, 1964. Bd. 55, H. 4. S. 410-427. 
13. Husserl E. Erfahrung und Urteil. Untersuchungen zur Genealogie der Logik. Hamburg : Claassen Verlag 1964. $477 \mathrm{~s}$.

14. Хайдеггер М. Кант и проблема метафизики. / Пер. с нем. О.В. Никифорова. Москва : Русское феноменологическое общество, 1997. 176 с.

\section{REFERENCES}

1. Filosofiia i relihiieznavstvo. [Philosophy and religious studies]. URL: https://tureligious.com.ua/ fales-miletskyj/ [in Ukrainian].

2. Podol'ny'j R.G. (1984). Osvoenie vremeni. [Mastering time]. Kyiv: Naukova dumka [in Russian].

3. Aristotel" "Fizika" [Physics]. Gl. IV. URL: http://lib.ru/POEEAST/ARISTOTEL/physic.txt [in Russian].

4. Soldatov, A.V. (1981). Ponyatiya prostranstva i vremeni v strukture estestvennonauchnoj teorii. [The concepts of space and time in the structure of natural science theory]. Leningrad: Izd-vo LGU [in Russian].

5. Azhimov, F.E. (2007). Ontologo-metafizicheskie proekty' sovremennoj zapadnoevropejskoj filosofii. [Ontological-metaphysical projects of modern Western European philosophy]. Voprosy' filosofii. 2007. No. 9 [in Russian].

6. Plato. (1900). Timaeus. Opera. Vol. 4. Ed. J. Burnet. Oxford [in English].

7. Kant, I. (2001). Prolegomena zu einer jeden kunftigen Metaphysik, die als Wissenshaft wird auftreten konnen. Stuttgart, Meiner [in German].

8. Bergson, A. (1923). Dlitel'nost' i odnovremennost'. [Duration and simultaneity]. Per. s fr. Peterburg: ACADEMIA [in Russian].

9. Kant, I. (1964). Sochineniya v shesti tomakh [Works in six volumes]. T. 3. Moskwa: My'sl' [in Russian].

10. Husserl, E. (1931). Ideas: General Introduction to Pure Phenomenology. London: George Allen \& Unwin Ltd. [in English].

11. Prychepii,Ye.M.(1971). Fenomenolohichnateoriia svidomostiE. Husserlia[Phenomenological theory of consciousness of E. Husserl]. Kyiv: Naukova dumka [in Ukrainian].

12. Gurwitsch, A. (1964). Der Begriff des Bewusstseins bei Kant und Husserl. Kantstudien. Bd. 55, H. 4 [in German].

13. Husserl, E. (1964). Erfahrung und Urteil. Untersuchungen zur Genealogie der Logik. Hamburg: Claassen Verlag. [in German].

14. Khajdegger, M. (1997). Kant i problema metafiziki [Kant and the problem of metaphysics]. Per. s nem. O.V. Nikiforova. Moskva: Russkoe fenomenologicheskoe obshhestvo [in Russian].

Гуйван Петро Дмитрович кандидат юридичних наук, заслужений юрист України, професор

Полтавського інституту бізнесу вул. Сінна 7, Полтава, Україна

\section{ВИВЧЕННЯ СУТНІСНОЇ ПРИРОДИ ЧАСУ В КОНТЕКСТІ СПРИЙНЯТТЯ ФУНДАМЕНТАЛЬНИХ ЯВИЩ БУТТЯ}

Ця прачя присвячена дослідженню вельми значимого у науці питання про зміст та сутність перебігу часу, його взаємин з просторовими явищами та сприйняттями цих прочесів людиною. Адже саме в людському усвідомленні плину часу тільки і можуть проявлятися назовні зміни конкретних явищ стосовно минулих подій $i$ їх очікування в майбутньому. Аналізується сутність часу, який у людському сприйнятті є тим явищем, що характеризується особливою емоиійністю усвідомлення як фактор, щзо зумовлює тимчасовість нашого перебування на землі. У изьому контексті констатується наявність серйозних труднощів процесу пізнання часу. Аналізується полеміка у філософській научі з приводу того, чи є час об'єктивним проявом реального матеріального світу, чи навпаки, він перебуває в площині суб'єктивного сприйняття, тобто виступає як певне духовне явище. Вивчені філософські ідеї, які 
заперечували об'єктивність часу або його існування взагалі, котрі були досить популярними упродовж тривалого розвитку наукової думки. Окрема увага в роботі приділена сприйняттю часових проявів матерії в межах онтології, розділу філософії, котрий вивчає фундаментальні принципи, загальні категорії сущзого. Розглянута теорія онтологічного ідеалізму, основна ідея якої полягала в тому, щьо ідеальне сприйняття формує у свідомості істотні відмінності між об'єктом та його уявним образом. Час за иією кониепцією сприймається як психологічний факт, внутрішній досвід людської душі. Конкретні явища природи інтерпретуються переважно із суб'єктивістських позичій, а важлива філософська категорія "річ у собі» як щцось об'єктивно існуюче не визнається поза свідомістю суб'єкта. Окремо оцінене так зване «трансиендентальне» спрямування. Згідно з парадигмами такої концепиії простір $i$ час є апріорними формами споглядання, котрі прагнуть надати визначеність та порядок пізнанню, але самі по собі не входять до його складу. У изьму полягає трансиендентальність простору та часу і протидія емпіричності пізнання.

Ключові слова: часовий перебіг, сучасне, минуле, майбутнє. 